\author{
Vladimira Ivandić \\ Ministry of Finance, Zagreb, Croatia \\ vladimira.ivandic@mfin.hr
}

Ivan Tolić

ZET, Zagreb, Croatia

ivan2.tolic@gmail.com

Niko Miljanić

Rident, Rijeka

miljanic235@gmail.com

\title{
EUROPEAN INTEGRATION AND GOVERNANCE - CHALLENGES AND PERSPECTIVES
}

Received: October 15, 2018

Accepted: December 20, 2018

Review

\begin{abstract}
European integration is largely seen as a process that has delivered stability and peace, as well as the economic prosperity of the Member States of the European Union (EU). It has helped to raise standards of living and build an internal market. But, there are more and more arguments that the EU decision-making system is not effective and the governance model is obsolete. Some are pointing out increasingly rising divergence on crucial EU policy matters. Others are arguing that the EU has been confronted with the challenge of heterogeneity, stressing the issue of immigration as the one of the most contentious policy matters currently facing the $E U$. Besides those controversial issues inside EU and different positions among member states there is Brexit.

The paper analyses in particular the issue of EU economic governance and one of its main pillars - the European Semester. The Country Specific Recommendations, as the integral part of the economic governance model are presented in a view of the new framework envisaged to tighten budgetary coordination and keep the deficit and debt levels in accordance to the EU rules.
\end{abstract}

Keywords: European integration, EU economic governance, European Semester, Country Specific Recommendations

JEL: O52 


\section{INTRODUCTION}

We - Europeans are living in the challenging world. There are so many issues that have confronted the process of the European integration. The new EU economic governance architecture that has been introduced after the financial and economic crisis is questioned in the light of the new developments. While the EU policymaking is getting broader agenda of cooperation, with almost no policy domain untouched, the results of the economic governance are not encouraging. On political front there is a huge distraction caused by the one country (United Kingdom) leaving the membership of the European Union. Therefore, today is more than ever appropriate to challenge the issues of the European integration and governance.

In accordance to the developments of the EU research this work firstly starts with the analysis of the European integration. As the second phase of the research on the European Union that occurred in early 1990s was completely oriented to the analysis of the EU governance process, the second part of this paper is devoted to the EU policy-making process. The main intention of the work is to analyse the European economic governance system and its main coordination instrument socalled the 'European Semester'(ES) with the associated Country Specific Recommendations (CSRs). Therefore, the third part of the paper is about the European Semester and the CSRs.

The concept of the European integration is presented to be followed by the analysis of the main actors of the EU integration and the institutional framework. Also, the historical development of the integration process is given in a form of the short overview. The issue of the European economic governance, especially the coordination and supervision of the fiscal policy is in the main focus of the work, as it is crucial for the further integration process. Third part is devoted to the implementation and effectiveness of the Country Specific Recommendations. Lastly, some conclusions are drawn upon.

\section{EUROPEAN INTEGRATION}

It is definitely true saying of Diez and Wiener (2018) that "There is surely no shortage of books on the European integration (EI)". After analysing the literature on the European integration one should agree that it is a booming field and it is difficult to make a selection of the appropriate literature as they are growing continuously. The vast majority of literature is dealing with the economic integration of countries and regions. This is still remained an intensely debated topics, both from a theoretical and empirical point of view. Theoretical discussions are essentially articulated around the concept of convergence/divergence in per capita income, as well as the possible trade-off between efficiency at country level and inequality at regional level. 
There is also considerable part of the EI literature that has in the main focus process of institutional-building and political integration at the European level. Most of the studies recognized existence of the two inter-related processes at the European level. First one is in regard to the policy competences that are delegated to the supranational level to achieve particular policy outcomes. The second one is related to the creation of the new bodies and institutions at the European Union level. Goetz and Mayer-Sahling (2009) comment that is a completely "new set" of political institutions with executive, legislative and judicial powers that have been established. The governance issue was recently introduced in the EI literature and more on the way how the power is exercised in the EU, having focus on the policymaking process.

At the beginning of the research on the European Union the primarily focus was on the explanations of the European integration process - the process where national sovereignty is transferred from domestic level to the European level (Diez and Wiener, 2018). Later on in the beginning of 1990s the governance issue started to dominate at the academic level. The studies that resulted from the research were more oriented to the policy analysis in order to explain the process of policy formulation and its implementation. That development coincided with and was stimulated by an increase in European level policy-making competencies of the Single European $\mathrm{Act}^{1}$ and the single market. As the European governance has developed over time it was evident that the concept included more and more areas of EU policy-making activities (Kohler-Koch and Rittberger, 2006).

The last decades were also characterized by the development of different integration theoriesthat have emerged after the first attempt to explain the EU integration done by functionalists and Monnet. Rosamond (2016)argues that "all important theories ${ }^{2}$ of the European integration generate multiple perspectives on the practice of the integration. Earlier integration theories were focused usually only to the one research objective - how to explain a state's decision in favour of supranational institutional building. Today the most of the European integration research topics deal with the work of the EU's formal institutions or with some particular policies". But, as Diez and Wiener (2018) conclude "the concise overview of the integration theory still remains rare". The reason is caused by the changing environment and the changing substance of the process, so any attempt to conceptualize the integration theory as a 'mosaic' that is constituted by a range of

\footnotetext{
${ }^{1}$ The Single European Act (SEA) was the first major revision of the 1957 Treaty of Rome. The Act set the European Community an objective of establishing single market by 31 December 1992.

${ }^{2}$ Those are: neo-functionalism (Hass, 1958, Lindberg, 1963), inter-governmentalism (Hoffmann, 1966, Taylor, 1982), federalism (Spinelli, 1972), liberal-intergovernmentalism (Moravicsik, 1998), multi-level governance (Marks, Hooghe and Blank, 1996), historical institutionalism (Sandholtz and Stone Sweet, 19979, and sociological constructivism (Risse in Diez and Wiener, 2003).
} 
distinct theoretical standpoints rather than a 'grand theory' would be the most suitable approach (Wiener, 2018).

In order to capture different aspects of the European integration process the elaboration of several elements need to be done. Firstly, the short historical overview of the development of the process of European integration is presented. Then, the institutional framework and main actors are reviewed as they are necessary for understanding the EU governance model.

\subsection{History and the main characteristics of the process of European integration}

The formal start of the process of the European integration was marked by the year 1951 when the six countries agreed upon the creation of the European Coal and Steel Community (ESCS). The so-called Treaty of Paris was signed on 18 April 1951 and came into force on 25 July 1952. It was for the first time that six European States agreed to work towards integration. The Treaty laid the foundations of the Community by setting up an executive known as the 'High Authority', a Parliamentary Assembly, a Council of Ministers, a Court of Justice and a Consultative Committee. The founders of the ECSC were clear about their intentions for the Treaty to be the first step towards a 'European Federation'. The common coal and steel market was gradually extended to other economic spheres.

The next event was also signing of another treaty - Treaty of Rome that was signed in 1957. With that Treaty the European Economic Community (EEC) was established and the European Atomic Energy Community. Unlike the ECSC Treaty, the Treaties of Rome were concluded for an unlimited period of time. Later on, in May 1992, the Maastrich Treaty was signed. It was important as it marked the beginning of a 'new stage in the process of creating an ever-closer union among the people of Europe' by giving the previous communities a political dimension. The Treaty covers issues of Economic and Monetary Union and regulates coordination of economic policies of Member States (MSs). The multilateral surveillance of this cooperation and financial and budgetary discipline were also introduced.

Besides the Treaties the European integration is also characterized by the enlargements of the countries. After the original six countries in 1973 three more countries (Denmark, Ireland and the United Kingdom) joined the EC. In 1981 Greece became the new member of the EC, marking the start of a decade of increased expansion and integration. Portugal and Spain become EU members in 1986. The biggest enlargement was in 2004 when ten new countries joined the EU- Cyprus, Czech Republic, Estonia, Hungary, Latvia, Lithuania, Malta, Poland, Slovakia and Slovenia. In 2007 Bulgaria and Romania become the $26^{\text {th }}$ and $27^{\text {th }}$ members of the EU and on June 1, 2013 Croatia joined the EU. The main important events of the European integration are elaborated in the following table (Table 1). 
Table 1. Timeline of the European integration (EI)

\begin{tabular}{|c|l|}
\hline Year & Event \\
\hline 1951 & $\begin{array}{l}\text { The Treaty of Paris is signed by Belgium, France, West Germany, Italy, } \\
\text { Luxembourg and the Netherlands (the 'Original Six'), creating the } \\
\text { European Coal and Steel Community (ECSC). }\end{array}$ \\
\hline 1957 & $\begin{array}{l}\text { The Treaty of Rome is signed as the first step towards establishing the } \\
\text { common market, customs union and free movement of capital and } \\
\text { labour. The European Economic Community (EEC) is established. }\end{array}$ \\
\hline 1958 & The first European Commission takes office. \\
\hline 1965 & $\begin{array}{l}\text { The Merger Treaty is signed in Brussels. It merges the executives of the } \\
\text { ECSC, EEC to become collectively known as the European } \\
\text { Communities (EC). }\end{array}$ \\
\hline 1973 & $\begin{array}{l}\text { Denmark, Ireland and the United Kingdom formally join the EC. } \\
1981\end{array}$ Greece becomes the 10 ${ }^{\text {th }}$ member of the EC. \\
\hline 1986 & Portugal and Spain become members of the EC. \\
\hline 1987 & The Single European Act (SEA) comes into force. \\
\hline 1992 & The Maastrich Treaty is signed. \\
\hline 1999 & $\begin{array}{l}\text { On 1 January, the Euro is launched as the official currency in 11 out of } \\
\text { the 15 EU MSs. }\end{array}$ \\
\hline 2004 & $\begin{array}{l}\text { On 1 May10 new countries joined the EU (Cyprus, the Czech Republic, } \\
\text { Estonia, Hungary, Latvia, Lithuania, Malta, Poland, Slovakia and } \\
\text { Slovenia). }\end{array}$ \\
\hline 2007 & $\begin{array}{l}\text { Bulgaria and Romania become the 26 }{ }^{\text {th }} \text { and 27th members of the EU on 1 } \\
\text { January. }\end{array}$ \\
\hline 2011 & European Semester was introduced \\
\hline 2013 & Croatia becomes the 28the Member State of the EU. \\
\hline
\end{tabular}

Source: based on www.civitas.org.uk/content/history

It is evident that the dominant feature of the European integration is about signing of the different treaties. Namely, the European Union is based on a serious of treaties, pacts and agreements which have increased over time. The second characteristic of the European integration process is connected to the issue of the membership. The growing number of the Member States and enlargements shaped the European integration process that has tended to occur in waves, particularly accelerated since the early 1980s.

For Schimmelfenning (2018) the history of the European integration is a story of growth. From its initial specialisation in coal and steel industry it developed in several areas. The European Union's roots, as well as start of the European integration were situated within the post-world war II context. At that time, the integration was indicated by the move towards founding the ECSC, and "motivated by the need to prevent future security threats based on the means of economic collaboration" (Wiener, 2018). These two industries had a key role and initiated 
regional collaboration that was based on a strategic decision to build and preserve a peace. The enhanced economic collaboration in other sectors appeared later on as it was agreed with the Single European Act.

The Schumann declaration led in 1951 to the European Coal and Steel Community among six countries (France, West Germany, Italy, the Netherlands, Belgium, and Luxembourg). The ECSC was then used as the institutional template for two proposed communities (the European Defence Community and the European Political Community) which included the formation of a common army, a common budget, and common institutions with significant legislative and executive powers. For Moravcsik (1999) it would have basically amounted to a European federation. Next important date occurred in 1955 when few politicians, including Jean Monnet, created an 'Action Committee for the United States of Europe'. Alesina and Perotti (2004) state that the "attempt to integrate European defence and foreign policy was not finished successfully".

The Treaty of Rome (1957) expresses in its preamble the necessity for Member States "to strengthen the unity of their economics and to ensure their harmonies development by reducing existing differences. This clearly communicates the willingness to contain (regional) disparities from the very start of the European integration process.

In 1987 the Single European Act (SEA) comes into force and modifies the Treaty of Rome with the aim to complete the formation of a common market. The national vetoes are abolished by introducing Qualified Majority Voting (QMV) in the Council of Ministers for areas relating to the single market (based on 'four freedoms'). The SEA was the first commitment by Member States to create 'European Union'.

In 1992 the Maastrich Treaty was signed. It turns the European Community into the 'European Union' $(\mathrm{EU})^{3}$. The Treaty also introduced the principle of 'subsidiarity" ${ }^{4}$ stated that "in areas which do not fall within its exclusive competence, the Community shall take actions, in accordance with the principle of subsidiarity, only if and in so far as the objectives of the proposed actions cannot be sufficiently achieved by the Member States and can therefore, by reason of the scale of effects of the proposed action, be better achieved by the Community". The principle of 'subsidiarity' is also a key pillar of European governance architecture and made full use of the advantages of diversity within the EU. All those events in

\footnotetext{
${ }^{3}$ The Treaty includes developments for monetary union and a chapter on social policy. It also introduced the concept of EU Citizenship, which give Europeans the right to live and vote in elections in any EU country. The Treaty is also relevant as it reorganised and redefined the European institutions.

${ }^{4}$ Article $3 \mathrm{~b}$ oftheTreaty.

5http://www.eirptreatoes.com/maastricht
} 
the history of the European integration can be called as 'critical juncturies'. They marked the way how the process was shaped and dictated further development not only at the EU level but also at the national-state front.

For Spolaore (2015) the process of the European integration is all about successes and failures. "The history of European institutional integration started with an early success (the formation of a coal and steel community, proposed with the Schuman declaration in 1950 and established with the Treaty of Paris in 1951), and a dramatic failure (the collapse of the defence and political community in 1952). Those two different experiences motivated the subsequent strategy of the European integration" (Spolaore, 2015). The failures have a special attention for Spolaore as they are "keys to understanding the beginning of the integration process, its setbacks, and the following path of European integration".

Alesinaet. al. (1997) see that the trade-off between costs and benefits is central to the political feasibility and stability of European integration. Potential benefits from full political unification include economies of scale in the provision of federal public goods (such as defence and security). Accordingly, Spolaore (2015) argues that the main issues lie in a general problem of the political economy: the trade-off between costs and benefits when heterogeneous groups are politically integrated under a common authority. Namely, "the formation of a European federation across heterogeneous populations, which share diverse social and economic structures, languages, cultures and identities, would come with several benefits, but also with high costs".

Namely, they state that the "political unification comes with significant costs when various groups speak different languages, share different cultural norms and identities, and have different preferences for public policies and institutions "(Alesinaet. al., 1997). The highest form of economic integration is a single market in which all producers and consumers are governed by the same rules and treated equally. If countries within a single market agree to coordinate their economic policies than is a case of the economic union, while in the event that countries within a single market agree to common policies in almost every sector one can speak about political union.

Caporaso (1998) concludes that in order to anticipate the future of the European integration it is necessary to understand the past events that shaped the process. He added "that the subject matter of the European integration is inherently dynamic and involves changes over time in the structure of supranational governance. To develop coherent explanations of constantly moving phenomena presents a daunting challenge."(Caporaso, 1998)

Spolaore (2015) elaborated issues of heterogeneity and points out that "the creation of layers of distinct and overlapping jurisdictions, each organized around a subset of public functions and policies with different economies of scale and heterogeneity costs, faces limitations and challenges both in terms of economic 
efficiency and political stability." Different populations with different histories, cultures and identities are likely to disagree over the type of government in charge of such a federation, so heterogeneity could be reason to explain failures to integrate in the past and that the "realistic supporters of European integration understand that convergence of political preferences through reduction of linguistic and cultural barriers, will be a slow and gradual process, which should take place naturally and consensually" (Spolaore, 2015). As a result, heterogeneity of preferences is mostly beneficial when people interact about rival goods but costly when sharing non-rival goods. The European integration has been much more successful when fostering economic exchanges and a common market, while it has stalled when attempting to pool 'federal' public goods, such as defence and security (Spolaore, 2015). Therefore, the idea of the European federation with its own budget and redistribution policies that could provide insurance against asymmetric shocks was accepted. A later on a growing literature has explored the links between measures of heterogeneity and political outcomes, such as the provision of public goods, the extent of redistribution, the quality of government, and the likelihood of civil and international conflict.

Some authors distinguish different dimensions of the European integration. Schimmelfenning (2018) is speaking about so-called sectoral integration that refers to a process through which policy areas or sectors are regulated at the EU level. There is also another dimension of the integration often called as a vertical integration. It is mainly about the distribution of competencies between the EU institutions. Once can speak about a horizontal integration that refers to the territorial extension of sectoral and vertical integration. That integration is commonly accepted ad the 'EU enlargement'.

Lastly, as another relevant feature of the European integration the matter of complexity is put forward. The complexity is caused not only by a big cast of actors (including governments, technocrats, interest groups, and voters), who in turn pursue a range of economic and political goals. The complexity of the institutional framework is also evident especially at the EU level where a new institutional constellation has been established. The several new institutions and bodies have been either established or substantially strengthened. Also some new roles have been given to parliamentary bodies. The reforms of European governance led also to an adaptation of the institutions, especially European Commission.

\subsection{Main actors and the institutional framework of the European integration}

The European Commission is in the centre of the process of the European integration and as Bauer and Becker (2014) state "It is powerful player in the European governance system. The Commission is an independent body and has an exclusive right of initiative". Namely, the Commission has a supranational 
executive's role in financing stability support, economic policy surveillance, coordination of national policy and supervision of the financial sector. In accordance to the Treaty the Commission role is to promote the general interest of the Union and take appropriate initiatives (Article 17 TEU). The Commission is also responsible for ensuring the application of primary and secondary EU law, executing the budget and managing programs, as well as exercising coordinative, executive and management functions. Its authority varies depending on the decision-making procedures governing the respective policy field.

But, its primary role is changing. When the European stability architecture emerged, its competences grew more complex. Commission expertise is employed at various stages in the process of granting financial assistance, mostly along with the European Central Bank (ECB) and IMF (so-called troika).

Bauer and Becker (2014) argue that "while the EU agenda-setting power is decreasing most decisions in economic governance depend on the Commission to make them work". The governance architecture of financial stability support involves the Commission in various capacities. It proposed decisions on granting assistance, negotiates conditionality agreements and monitors compliance. The Commission in liaison with the ECB (and where appropriate with the IMF) also monitors the implementation of the adjustment programmes. It also examines changes to the adjustment programme and if observes significant deviations it makes proposals on the further steps. For Bauer and Becker (2014) "the Commission fulfils crucial tasks in all phases of the particular policy cycle".

In regard to the national institutional framework involved in European integration and governance De Streel (2013) observes that was initially' relatively simple'. Namely, the EU requirements in that regard were mainly related to the provision of statistics and were minimal. There were also no clear sanctions if the Member States manipulated with statistic data. Such situation existed until 2009 when a new regulation on national fiscal statistics was adopted. A year later was revised, besides other things, to increase the investigation power of Eurostat. In 2011 with the introduction of the European Semester and 'Six-pack' the minimum quality for the budgetary framework defined as 'the set of arrangements, procedures, rules and institutions that underlie the conduct of budgetary policies of general government' was introduced. Thus, all Member States must have in place public accounting systems, subject to internal control and independent audits, adopt realistic macroeconomic and budgetary forecasts and establish a credible, effective medium-term budgetary framework ${ }^{6}$.

The European integration has achieved results which would not have been possible by individual Member States (MSs) acting on their own. Membership of the European Union confronts government with a set of particularly testing

${ }^{6}$ Article 5 Regulation 473/2013 
organizational and managerial challenges. On one hand it requires abilities to form coherent national positions in the EU decision-making. On the other, the EU accession calls for institutional-building, supplant of new institutions that embody a new type of organizational culture and new way of policies.

The role of directly elected European Parliament (EP) is rapidly changing as it is taking a new tasks becoming a co-legislator. Through the co-called co-decision procedure a number of regulations and directives need to be adopted by both the Council and the EP before they become binding 'legislation'.

The process of policy coordination within the European integration was link to the deliberative and consensual quality of EU decision-making. "Deliberation and consensus-seeking have long been taken as the behavioural hallmarks of supranationalism, but in the post-Maastrich period they have imposed themselves as dominant norms regulating the relations between national actors" (Bickerton, Hodson and Puetter (2015). European Council is a deliberative and consensusbuilding body per excellence.

There are also some newly created institutions that are established and have autonomy (by way of executive or legislative power), as well as a control over their own resources. They fulfil certain functions and have a mechanism for the Member state representation as a part of their governance structure. Those new institutions include the European Central Bank, the European External Action Services (EEAS), the European Stability Mechanism (ESM) and numerous regulatory and executive agencies.

The process of the European integration has evolved through times, following by the evolution of the European governance especially over the last decade. De Streel (2013) describes it as a'remarkable process'. The establishment of European economic governance is mainly based on the Treaty on the Functioning of the European Union (TFEU) and regulations adopted by the Council while the implementation relies mainly on recommendations proposed by the Commission and adopted by the Council. "Those recommendations do not have direct binding effect as their violation cannot lead to an infringement case at the Court of Justice. However, they have indirect binding effect as their violation may lead to an investigation and the imposition of sanctions by the Council"'(De Streel, 2013).

Co-ordination between actors is built into the Treaty for economic, fiscal and employment policies with a system of guidelines and multilateral surveillance. The Council assumes a key role in relation to coordinating processes. Hodson and Maher (2000) state "the Commission's role of analysis, neutrality and synopsis is different from the one under the classic Monnet method, but also weakened with its agenda-setting function". The Commission can trigger a number of procedures, but in the form as a recommendation and not proposal. There are opinions that the 
Commission is gradually losing political clout, while several authors (like Bauer and Becker, etc.) are on contrary arguing that the role of the Commission has been considerably strengthened after the latest financial and economic crisis.

In the time of crisis, the role of the Commission was not very visible, but after the crisis "in the reformed economic governance architecture its role has changed and has been more strengthened". Due to the new given responsibilities the Commission has been in charge for the implementation of numerous reforms. Bauer and Becker (2014) state the Commission "has been entrusted with ever wider and deeper implementation tasks that are of the high political importance". Also, several new developments happened after the financial and economic crisis and influenced that the overall European integration setting was changed. The EP has been empowered and "progressive political leadership by the European Council and proliferation of new regulatory institutions has been influenced at new power settings" (Bauer and Becker, 2014). The power relations between institutions also changed due to the differences within the certain policy area.

\section{EUROPEAN GOVERNANCE}

The dominant feature of EU governance is a 'community method' for which Scharpf (2003) used the term 'joint-decision mode'. Such a method is characterised by a strong role of the European Commission in the formulation and execution of Community legislation. All legislation is adopted by the Council of Ministers, but before a Council of Ministers several committees discuss and work out to find compromise solutions. For some authors (like Hodson and Mahler, 2001) as a reaction to the imminent risk of deadlock in Community decision-making the "new modes of governance' were introduced so called the 'open method of coordination' (OMC). Such a method of governance was established by the Maastricht Treaty $^{7}$ as an instrument destined for the co-ordination of national primarily economic policies through the use of recommendations and guidelines. It departs from the Community method (of legislating through regulations and directives) relying on 'soft lax' which is not legally binding and has no legal sanctioning mechanisms against non-compliance. OMC is about 'benchmarking', 'peer review' and 'best-practice'. The underlying assumption is that participating actors can learn from assessment and comparison (Eberlein and Kerwer, 2004).

Lebessis and Paterson (1998) are of an opinion that the open method is being focused on horizontal learning processes and peer pressure where individual action runs counter to broadly accepted principles. They also see OMC as a "dynamic process and decentred as modus operandi without any particular rule or single policy objective as an objective". Swyngedow (2004) argue that 'since the rules

\footnotetext{
7 The OMC was officially introduced in May 2000 at the Lisbon European Council.
} 
and practice of participation do not guarantee equality between actors the multitude of actors is still far from promoting EU democracy'.

Another element of EU governance is its multi-level nature. The concept of 'multilevel-governance' $(\mathrm{MLG})^{8}$ represents a system of continuous negotiation among governments. It assumes that decision-making authority is not monopolised by the governments of the MSs, but that is diffused to different levels of decision-making. European policymaking is also characterised by specific features that distinguish it from policy-making at national level. These features are linked to the institutional structure of the EU and its role vis-à-vis the Member States.

The EU itself has no competences to implement policies directly. The implications are that the EU is dependent on national governments for policy implementation. Therefore, Tommel and Verdun (2009) conclude that the European policy-making often 'entails strategies and procedures that direct the behaviour of decentralised actors on due implementation'.

Kohler-Koch and Rittberger (2006) added that "despite the omnipresence of 'governance' in the study of the EU governance is still ambiguous and underspecified as a concept, let alone as a theory. But as the term 'governance perspective' suggests, governance research on the EU comprises works with a shared interest in the transformation of governance beyond the state through normative and empirical-analytical lenses". Furthermore, they argue that in spite of rapidly and increasingly diversified literature on (new) modes of governance in the EU policymaking, theoretical reflection and empirical research have not resulted in a clear conceptualisation of the governance approach, let alone in a stringent methodology for its application to the analysis of new forms of policymaking.

For Tommel and Verdun (2009) 'a wide variety of competing concepts, interpretations, and perceptions of the term governance and its meaning coexists in the literature'. Wallace and Young (1997) argues that a special form of policy coordination involving national and Community officials allow the Member State governments to retain considerable control but still transform the ways in which states traditionally go about doing their business.

\subsection{Institutional framework of the $E U$ governance}

Current institutional framework of the EU governance is contemplated around the open method of-coordination (OMC).In practice it means that the EU economic governance consists of three Council committees ${ }^{9}$ that are involved in the everyday

\footnotetext{
${ }^{8}$ It was developed by Marks in 1993.

${ }^{9}$ The Economic and Finance Committee (EFC) is an advisory committee of ECOFIN and has consultative and review functions, being responsible for the co-ordination of fiscal policy through the operation of the Stability and Growth Pact. Another Committee is Economic Policy Committee (EPC) with a role to monitor structural policy.
} 
work and preparation of the Council of Economic and Finance Ministers (ECOFIN). It is often saying that such co-ordination is associated with convergence towards predetermined targets, as the Member States agree on keeping the agreed economic indicators up to the certain limits, namely to maintain their budget deficits within 3 per cent of GDP and their medium-term budgetary position close to balance or in surplus. Therefore, the European economic governance is enforced through multi-lateral surveillance and the excessive deficit procedure. The former requires each Member State to formulate a Stability Programme or Convergence Programmes in the case that the state is outside the euro-area. In the event of deviation from the predetermined targets, the Council can issue a recommendation for corrective action. In the event of an infringement the Excessive Deficit Procedure (EDP) can be triggered, culminating in formal sanctions, including fines.

The main instrument for a co-ordination of economic policies are so-called the Broad Economic Policy Guidelines (BEPGs) that are drawn up annually by the Commission and Council and adopt by the European Council. The consistency of national economic policies with the economic objectives of the Union was assessed. The economic policies of Member States are coordinated through the BEPGs (in accordance to Article 121.2 of TFEU) as an annual exercise.

In 2011, the European Semester was introduced to make the coordination of national economic polices more effective. As Benassy-Quere (2015) comments "the objective of the European Semester was to transform BEPGs into a binding process".

European economic governance could be described as a system of multilateral negotiating or networking in order to coordinate national policies. It is often state that it takes form of supranational, European economic government. The economic governance framework was established with the Treaty of Maastricht (in 1992) and enforced with the Stability and Growth Pact (SGP) in 1997. According to De Streel (2013) the economic governance is based on three main areas, namely:

1. the coordination of the Member States' economic policies (Article 121 TFEU),

2. the prohibition of financial solidarity among Member States (Art 125 TFEU) except in very extraordinary circumstances beyond the control of the States (Art 122 TFEU) and the prohibition of monetary financing by the European Central Bank and the National Central Banks (Art 123) and

3. limits to fiscal deficits to $3 \%$ of GDP and public debt to $60 \%$ of GDP (with sanctions decided by the Council in order to force sustainable fiscal policies).

The economic governance at European level takes two forms. The first one is socalled a 'soft' and it is known as the Open Method of Coordination. It also rests on moral persuasion and peer-pressure. The second one is a 'hard' governance and it is 
based on a mechanism of material sanctions and it is best exemplified by the Stability and Growth Pact.

The current governance model is result of several changes introduced to make it more efficient and transparent. Therefore, the economic governance framework was reformed several times. The first reform was in 2005 and initiated with the situation in which the Stability and Growth Pact was not strictly implemented. Schuknecht et al. (2011) are arguing that on the request of some MSs (most vocally France and Germany) the full application of the provisions of the corrective arm of the Pact was not followed. Its strict implementation was blocked. The Commission recommendation to move a step further in the direction of sanctions under the excessive deficit procedure (EDP) was rejected. The reasons/arguments put forward were mainly concentrated around the fact that the specific situation of each Member States were not taken into account, especially phase of the economic cycle in each country.

The main aim of the reform was to strengthen the surveillance and coordination, as well as to clarify some procedures related to the Excessive Deficit Procedure (EDP). Reform was also targeting to enable a better national ownership and allow for more details in the recommended economic policy.

The second reform of the economic governance was initiated after the European economic and financial (debt) crisis. Namely, during the crisis it was evident that the current EU governance model was not properly designed to tackle such circumstances. Therefore, in 2011 the effectiveness of the Stability and Growth Pact was once again put into question. It was further reinforced with the so-called 'Six-pack'10, which has been created to enhance the surveillance in the Excessive Deficit Procedure and sanction procedures. Several other features were also introduced in the system of economic governance, of which the minimum requirements for budgetary planning and the Macroeconomic Imbalance Procedure $(\mathrm{MIP})^{11}$, are the most important.

In the reform that was initiated in 2013 the so-called 'Two-Pack' was introduced with common budgetary timeline and rules for Member States. The new element was also a system of enhanced economic and budgetary surveillance for those Member States that have experienced financial stability difficulties or those that

\footnotetext{
${ }^{10} \mathrm{Six}$-pack consists of five regulations that are aimed to strength the implementation of efficient budgetary surveillance and enforce measures to correct excessive macroeconomic imbalances, as well as to introduce requirements for budgetary frameworks in the Member States.

11 The MIP is also a form of a surveillance mechanism which is aimed to identify the potential risk in the early stage and prevent macroeconomic imbalances and correct those that are already in place.
} 
receive financial assistance from the European Financial Stability Facility ${ }^{12}$ (EFSF) and the European Stability Mechanism (ESM) as a permanent crisis resolution mechanism for euro-area Member States. There for the enhanced SGP became a part of the European Semester that presents the EU's annual cycle of economic policy guidance and surveillance.

Although the European economic governance model went through all that changes it is evident that the framework is still not properly enforced. Namely, the governance model is still incomplete since it did not prevent the build-up of fiscal imbalances in some Member States, as well as it failed to identify (and remedy) the triggers of the crisis in countries (like Ireland and Spain).

There is also problem with the enforcement mechanism in the European economic governance model. The enforcement mechanism used by economic governance present two main differences compared with the standard enforcement based on sanctions decided by courts. The first difference is that enforcement of economic governance rules is mainly based on voluntary actions by Member States and peer pressure, and, only as a last resort, on sanctions. The second difference is that the sanctions are not decided by independent courts, but are proposed by the Commission and decided by the Council. Unfortunately, the last decade shows that such an enforcement system was not very effective (De Streel, 2013).

Also, one of the issues of the EU economic governance model is a problem with the national ownership. In spite that all reforms have been tackled that issue in order to influence and improve the national ownership still a lot need to be done. The ownership was tried to improve by requiring a minimum quality for national fiscal institutions, thenwith the establishment of a national correction mechanism (in parallel to the excessive deficit procedure) and by the coordination of policies during the first semester of the year before the adoption of national decisions during the second semester.

De Streel (2013) concluded that recent reforms also increase the possibilities of sanctions which may be imposed earlier in the Excessive Deficit Procedure, and also during the annual multilateral surveillance.

The Commission conducted a review of the SGP in 2014 and highlighted both the strengths and the possible areas for improvement of the framework of the economic governance. The year after (in 2015) the Commission issued guidance on how it intends to apply the SGP rules to strengthen the link between structural reforms, investment and fiscal responsibility in support of jobs and growth.

12 EFSF was introduced in June 2010 for the euro area MSs and provided financial assistance to Ireland, Portugal and Greece. 
The current structure of the economic governance framework is based on four pillars (De Streel, 2013) of which each of them has its own objectives and methods, with strong differentiation between the countries which are in the euro-area and those which are outside. The first pillar of economic governance is a fiscal surveillance that aims to control, and if necessary correct, the fiscal imbalances of the Member States. It consists official rules - i.e. rules related to government deficit - the $3 \%$ deficit rule and rule related to government debt (the $60 \%$ debt rule and the $1 / 20$ per year correction in case it is breached). The second pillar of economic governance is a surveillance and enforcement mechanism that aims to prevent and correct macroeconomic imbalances within the EU that have spill-over effects. It consists of a scoreboard of early warning macroeconomic indicators for the timely identification of internal and external imbalances and the surveillance procedure ${ }^{13}$. Third pillar of the economic governance relates to the coordination of national economic and social policies in order to prevent fiscal and macroeconomic imbalances and to stimulate growth and jobs in Europe. The fourth pillar is on financial solidarity.

\section{EUROPEAN SEMESTER AND THE COUNTRY SPECIFIC RECOMMENDATIONS}

The European Semester (ES) is one of the main pillars of the European economic governance model. It is called European Semester as during that time period each year Member States' budgetary, macro-economic and structural policies are coordinate in order to allow states to take Commission consideration into account during their national budgetary processes and in other aspects of their economic policymaking.

Within the framework of the ES several key stages are established. Starting point of the European Semester (ES) is a publication of the Annual Growth Survey (AGS) and the Alert Mechanism Report (AMR) usually in November/December of the preceding year ${ }^{14}$. AGS sets out EU priorities for the coming year to boost growth. Usually in June the Commission drafts Country Specific Recommendations (CSRs) proposing economic policy measures for each Member State, depending on the country's economic and social performance in the previous year. The recommendations are based on the results of a country report and reflect the priorities set out in the AGS. The CSRs are then adopted in July by the European Council. ${ }^{15}$

\footnotetext{
${ }^{13}$ There is so called preventive and a corrective phase while the preventive phase includes the Commission's Alert Mechanism Report (AMR). The corrective phase refers to the Excessive Imbalance Procedure (EIP), the corrective action plans, the assessment of the Member State's corrective action and potential financial sanctions.

${ }^{14} 2017$ Semester Cycle (AGS and AMR) started 27 November 2017.

${ }^{15}$ Implementation of the 2017 Semester Cycle was at ECOFIN Council (EE) on 24 January 2018. On 28 June 2018 the EC presented its CSRs 2018.
} 
The CSRs are tools designed to enhance the economic growth and job creation in Europe, while maintaining sound public finances. They are proposed by the Commission within the framework of the European Semester, based on its assessments of Member States' medium-term budgetary plans and economic reform programmes in the light of broad policy priorities outline in the AGS.

The Commission, as the integral part of the European Semester cycle produces indepth assessment of each Member State's implementation progress against the previous year's CSRs. CSR implementation is assessed on the basis of actions taken rather than observed outcomes. Deroose and Griesse (2014) conclude that "the quantification of qualitative information is notoriously difficult and subject to judgement issues". It is also observed that CSRs are not all equally important, as within each country, but also across countries.

\subsection{The Country Specific Recommendations - implementations and issues}

The Country Specific Recommendations (CSRs) provide guidance to the EU Member States on macro-economic, budgetary and structural policies in accordance with the Treaty on the Functioning of the European Union ${ }^{16}$ (TFEU). They are issued within the framework of the European Semester with the aim to boost economic growth and in the same time maintaining sound public finances and preventing excessive macroeconomic imbalances. Therefore, the CSRs include both fiscal requirements based on the preventive arm of the Stability and Growth Pact and other requirements based on the prevention of the macro imbalances. In addition, they include advices for the national reforms in order to achieve more 'inclusive and sustainable growth'.

The European Commission identifies priority areas for action each year in its AGS that mutually reinforce one another. The European Semester focuses on those areas (fiscal responsibility, structural reforms, investments and recently employment policy and social protection). The CSRs focussed on those four priorities. First one is in regard to the investments that will support growth in EU. In order to achieve such objectives, barriers to financing and launching investment projects were envisaged. Then the second area is on structural reforms in product, service and labour markets that raise productivity, competitiveness and investment, as well as in the financial sector to ease access to finance for investment. The third area is about sound fiscal policies that strike a balance between short-term stabilisation and long-term sustainability. In MSs with weak fiscal position (both deficits and debt) further efforts are required to fix their balance sheets, and in MSs with fiscal space expansionary stance towards productive investment should be taken. The fourth area is in regard to the improvement of employment and social protection.

\footnotetext{
${ }^{16}$ Article 121 and 148.
} 
The Country Specific Recommendations was a first time issued in 2011 to the twenty-two countries, except Member States with macroeconomic adjustment programme linked to EU financial assistance (Greece, Ireland, Portugal, Latvia and Romania) which do not receive CSRs.

The number of CSRs given to the MSs during the first period until 2015 every subsequent year increased, namely from 118 in 2011 to 138 in 2012, then to 141 in 2013 and 157 in 2014. But, since the 2015 CSRs have been prepared in line with the co-called streamlined approach that is characterised by fewer and refocused CSRs. Hradisky and Ciucci (2018) add that "under the streamlined Semester, the recommendations also put greater emphasis on the objective to achieve, while largely leaving definition of the measures needed to attain it to the discretion of national authorities". The total number of recommendations issued to MSs was more than halved in 2018 and amount only 73 CSRs. The reason of such reduction Hradiskyand Ciucci (2018) are explaining with the new focus and prioritisation of the Semester and the fact that some policy areas that were covered separately in one Semester cycle have been merged during the next cycle". The number of MSs for that the CSRs have been issued also has gradually increased as the Member States that receive the financial assistance successfully exited from the related programmes (Ireland, Portugal and Cyprus).

The experience with ES and the implementation of CSRs after several years of the implementation clearly shows that results are not encouraging. In the Graf 1 the implementation of CSRs is presented since 2011. The best results and the highest percentage of full progress were recorded in 2011 which was the first year after the CSRs were introduced. But, it should be noted that the different methodology were used for that year (with only three assessment categories ${ }^{17}$ ). These results cannot be converted into the current five-point scale, so the interpretation of the achievements should take that into account. It is also evident from the Graf that in year 2016 the percentage of the full implementation of CSRs was less than in the previous year. Also, for the last four years almost the same percentage of the CSRs is labelled with "no progress" with just slightly improvements in 2016.

\footnotetext{
${ }^{17}$ Namely, 'no implementation', 'partial implementation', 'full implementation'.
} 
Figure 1. Implementation of country-specific recommendations: yearly assessment in each consecutive year

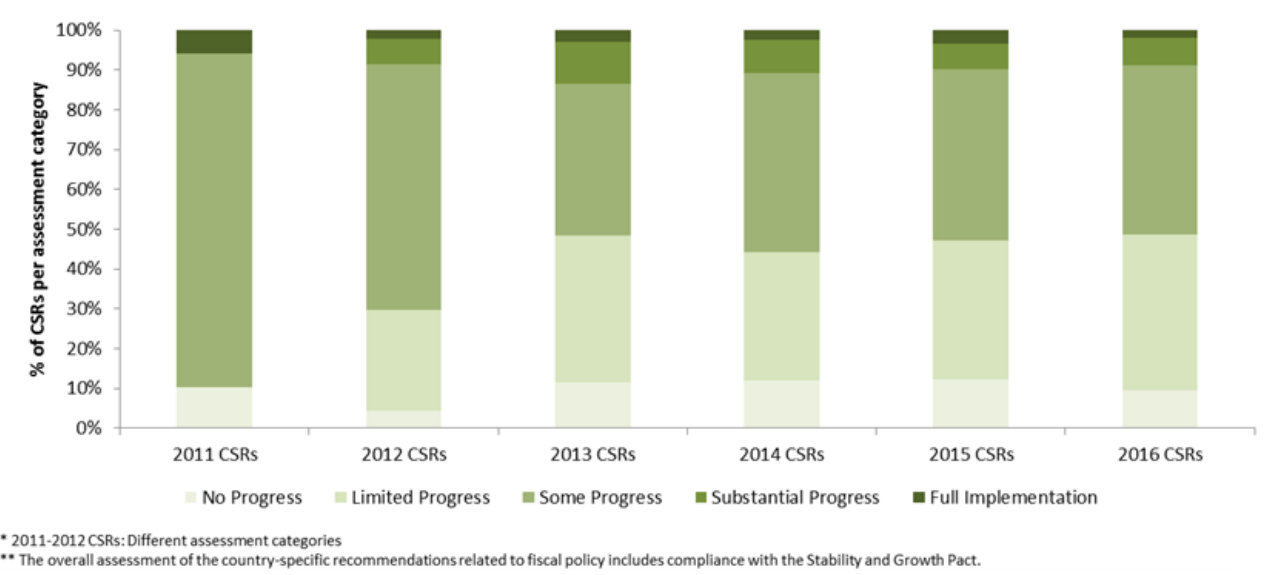

Source: Communication from the Commission on 2017 European Semester:

Country-specific recommendations (EC, 2017)

Looking also at the first years of the CSRs implementation it is noted (see Graf 2) that CSRs that were categorized as 'fully implemented' decreased significantly. In contrast to that trend the CSRs implemented with 'limited' progress increased dramatically from $24.5 \%$ in 2012 to $43.3 \%$ in 2013 . The same trend continues in 2014 where the percentage of CSRs implemented with 'limited' progress reached almost 45\%. Gern, Jannsen, Kooths (2015) also observed that the CSRs have been insufficiently addressed by Member States. Only around ten percent of recommendations have been fully or substantially met, meaning that Member States have adopted and implemented measures that are appropriate or go a long way in addressing the country-specific recommendations. At the same time, the share of recommendations which have been insufficiently addressed, where adoption or implementation is at risk or no measures have been announced or adopted at all (limited or no progress in implementation) has risen from 29 percent in 2012 to 46 percent in 2013 and 48 percent in 2014. 
Figure 2. CSRs - first years of implementation

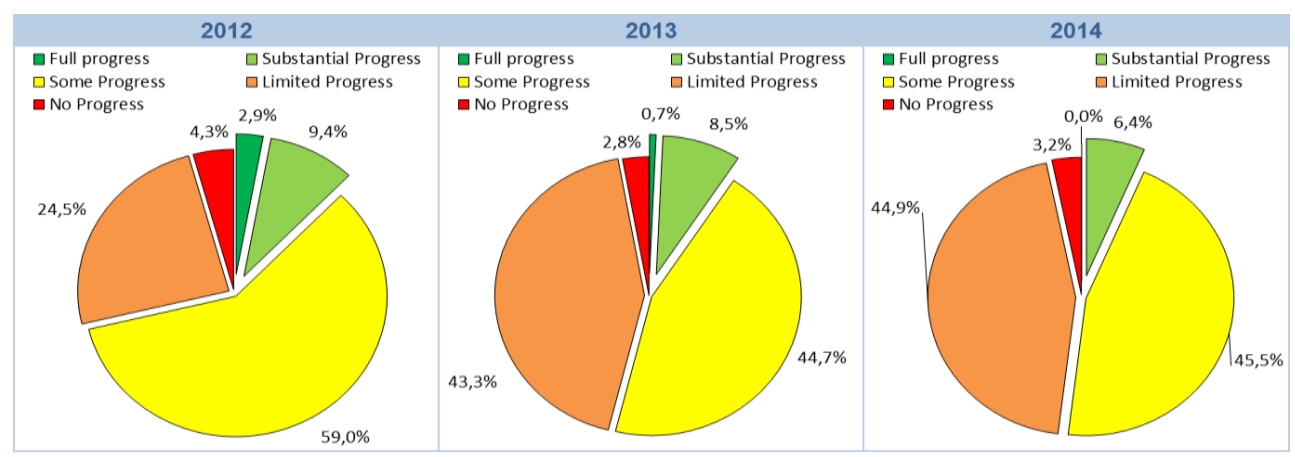

Source: Gern et al. (2015) Economic policy coordination in the euro area under the European Semester, Kiel Institute for the World Economy

Only around one third of the country-specific recommendations issued until 2017 have been implemented with 'limited progress', while $44 \%$ of them were implemented with 'some progress' (see Graf 3). The reasons for such relatively poor results are often contributed to the several factors of which one is timing. Namely, the implementation of reforms takes time, so it was suggested that it is important to assess the process over the medium term and not only the short term perspective. Ragot (2017) is of opinion that the question of the timing is relevant as some reforms may have effects in the long run, while others may have a direct effect already in the short run.

Since the start of the European Semester in 2011, the pace of progress - as assessed one year after the adopting of the recommendations - has been slightly decreasing. The EC is arguing that this could be because politically easier reforms were done first and because of the greater sense of urgency during the crisis (EC, 2017). 
Figure 3. Overall implementation of 2011-2017 CSRs

Full implementation 9\%

No progress $5 \%$

Substantial

progress $17 \%$

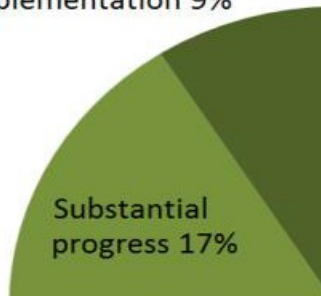

Limited progress $25 \%$

Some progress $44 \%$

Source: European Commission, 2018 European Semester: Country-specific recommendations

Deroose and Griesse (2014) argue that "an interesting angle from which to look at CSRs implementation by country is the national electoral cycle. Namely, the average implementation was superior when CSR adoption was not followed by an election within 12 months. The Member States also act in the way to 'pick the lowhanging fruit' first and more challenging set of CSRs in subsequent rounds of the European Semester ". Ragot argues (2017) that "it raises political issues, as it may involve some financial costs or the use of limited political capital. He also noted that "one cannot expect an ownership of different types of reform to be the same. In addition, the tools to incentivize reform implementation cannot be the same for the all types of reforms, as their legal basis differs" (Ragot, 2017).

Regarding the question of the policy areas identified within the CSRs it is evident from the Graf 4 that they are covering a very broad set of policy areas - from public finances and taxation, to structural policies and public administration, including a wide range of sub-activities. The implementations of policy reforms activities during the period 2011-2016 on average is relatively modest as the degree of progress ranges between 'limited' and 'some' for most policy areas identified, meaning that there is still work to be done before the reforms are fully implemented and deliver results.

The best result in the implementation is for financial sector reform and public finance. Deroose and Griesse (2014) argue that "the financial sector reform recommendations (most of which concern the banking sector) stronger implementation may be related to the urgency of policy actions in view of financial stability concerns and concomitant market pressure in several Member States. For 
public finances, the stronger implementation record may reflect not only market pressure, but also the fact that fiscal recommendations are in large part derived from the Member States 'obligations stipulated by the EU's Stability and Growth Pact, such as the reduction of the general government deficit to below 3\% of GDP or reduction of public debt". These rules come with significant enforcement powers, notably financial sanctions, so they may spur compliance (Deroose and Griesse, 2014).

The lowest implementation records of CSRs are usually within the area of tax reform as characterized like a politically highly sensitive and with the direct distributional implications (Deroose and Griesse, 2014). Similar is also in area of education and public administration reform where the implementation of CSRs are relatively low. It is understandable as all policy areas do not have the same economic or political relevance, so it would be desirable to make a hierarchy of them.

Figure 4. Policies areas covered in the country-specific recommendations

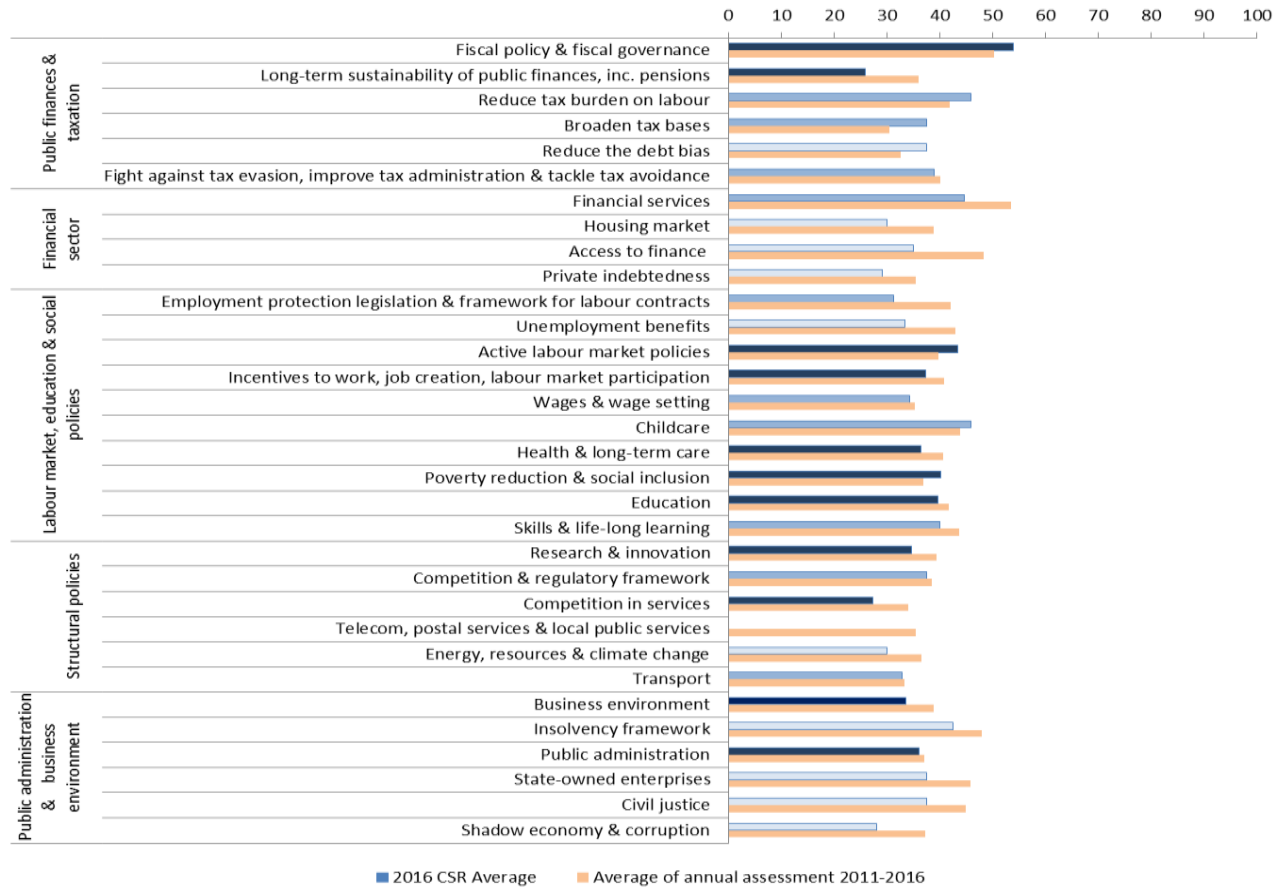

Source: European Commission, 2017 European Semester: Countryspecificrecommendations

Darvas and Leandro (2015) in their analysis of the implementation at the CSRs from 2011-2015 they calculate a European Semester reform implementation index (which ranges between zero where is no progress and one where is full implementation of CSRs). Their study shows that the track record of 
implementation of CSRs is modest and deteriorating and that the average value of the reform implementation index for the $21 \mathrm{EU}$ countries for which recommendations were made every year since 2011 was 40 percent. Finally, they conclude that "Despite the collective decision to create the new system of policy coordination, the findings how that the European Semester has been rather ineffective. This failure highlights the fundamental problem of policy coordination in the EU: national policymakers are accountable to their national parliaments and focus on national interest, which in many cases differ widely in different Member States"(Darvas and Leandro,2015). The implementations of CSRs for the period from 2013-2017 are almost the same and they show on average relatively poor results as it ranges between 'limited progress' and 'some progress', meaning that on average Member States fell short on adopting measures to address the recommendations. It should be noted that the deterioration in the implementation of CSRs coincides with the streamlining of the CSRs which reduced their number and length.

Besides the Commission' assessments of the implementation of CSRs there are not so many others. Recently, Efstathiou and Wolff (2018) produced interesting analysis but using the dataset of scores from the Commission. They transformed scores into numerical variables in order to find the average implementation scores. Despite the simplicity of the synthetic indicator (with equal weights assigned to each CSRs the score per country) their analysis coincides with the Commission's qualitative country assessments ${ }^{18}$.

One should argue that the relatively disappoint results of the implementation of the CSRs are achieved because there are so many different procedures and rules in place introduced by different regulations and that is difficult to follow all that. There is also view that the current system "strengthens procedures, but not institution and that the role of the Commission has been weakened, while the Eurogroup lost authority" (Pisani-Ferry, 2018).

In regard to the role of institutions within the ES the debate is going on the relevance of the inclusion of other especially non-EU institutions, especially the International Monetary Fund (IMF). Pisani-Ferry (2018) is of opinion that "the IMF and ECB only complicate situation for the countries that are under the financial assistance programmes". On the other hand, he is he is in favour of the introduction of a new bodies in the institutional structure of the European

\footnotetext{
${ }^{18}$ The countries with highest implementation scores were Finland, the United Kingdom, Slovenia, Malta and Spain. The implementation was the lowest in Luxembourg, Slovakia, Hungary, Germany and Bulgaria.The implementation in countries including Luxembourg and the Netherlands has fluctuated significantly, but they conclude that "It is beyond the scope to examine the political economic factor driving the country actions. The factors include issues such as the capacity of a country to put in place reforms, electoral cycles and the business cycle".
} 
Semester, as well as for the broadening the remit of existing (like a fiscal councils). $\mathrm{He}$ is also proposing to create the National Competitiveness Councils in order to monitor current accounts, development in exchange rates etc.

It is evident that proposals to improve current EU governance framework are headed in several directions. Most of the proposals are concentrated to the applications of current rules, pointing out that the sustainability of the public finances is more relevant economically than the fiscal rule - 3\% deficit and $60 \%$ debt ceilings (De Streel (2013). There is also many criticisms about the calculation of the (structural) deficit, as it is rather complex and methodology is not so transparent. Comments are that such situation is not in favour of the implementation of the reforms prescribed by the CSRs as it is difficult to explain it to the general public, "hence the case for painful socioeconomic reforms to meet those rules is more difficult to make" (De Streel (2013).

Regarding the improvements within the implementation of the CSRs the issue of the national ownership dominates. There are views in favour of enhanced dialogues between institutions in order to raise awareness of the effects of the budgetary decision between Member States, as well as strengthening the oversight of parliamentary bodies over their executives. Furthermore, the sanctions mechanism exists, but it was not applied to the Member States that are not performing well.

Several authors are arguing that the better transparency is needed for the functioning of the whole system and especially for the explanation of the methodology in the case of EDP. De Streel (2013) observes regarding the fines that "their credibility and effectiveness depend on their timing and on the situation of the Member States concerned. The fines are effective if they are imposed or threatened to be imposed early in the surveillance procedure and when the Member State concerned does not face a liquidity of solvency crisis".

It is also true that the MSs may respond to recommendations on structural policies with so many measures and that would be difficult to say whether these measures will achieve intended results. Zuleeg (2015) is pointing out that the "implementation gap will remain, craven by a fundamental political economy problem; namely because of the fact that the implementation of reforms is decided at the EU level and need to be justified politically at the national level":

Regarding the Country Specific Recommendations there is a common agreement that they are usually precise, but that contain a number of targets. Alcidi and Gros (2014) argue that "they consist of other policy recommendations which can be quite vague and contain exhortations, without giving any precise target to be achieved. The implementation of the structural part of the CSRs is also often too vague to allow one to judge about the implementation. They are also arguing that "the politically and financially strong countries tend to ignore CSRs, while the 
politically and financially weaker countries usually respond to recommendations on structural policies with many measures, but it is often difficult to say whether these measures will achieve the intended results" (Alcidi and Gros, 2014). Therefore, Schneider, Zuleeg and Emmanouilidis (2014) propose that "the Commission together with the European Parliament focus the process on a smaller number of key priorities for each country, with a strong attention on the future growth". They are in favour of the strict implementation of CSRs and the introduction of sanctions if the key recommendations are not implemented.

Efstathiou and Wolff (2018) make a remark that "the ES exercise is a very difficult to digest and communication of key analyses and recommendations could be significantly improved to make them more accessible". Regarding the transparency of the European Semester some authors, like Gern, Jannsen and Koots (2015) state that "the transparency of the ES could be strengthened by being more explicit on the theoretical foundations on which recommendations are based". They also stress that "it is particularly important to elaborate a coherent theoretical framework for those events that threaten the functioning of the EU economic governance as a whole and that a common understanding is crucial for creating ownership for policy initiatives that are supposed to address common interest shared by all MSs". Namely, as the economic policy is left under the authority of the MSs the implementation rate of CSRs will remain relatively low whenever conflict with the aims of national authorities. Furthermore, the decision-making process is complicated even more because of "the mistrust among Member States and between them and the Commission, so it represents an essential barrier that needs to be overcome" (Zuleeg, 2015).

\section{CONCLUSION}

It is obvious that in spite of the reforms introduced to improve the European Semester still some shortcomings exist. The CSRs implementation record is marked by a downward trend since the introduction. The experiences so far show that the current governance framework relies on a complex set of institutions and procedures in order to provide recommendations to the MSs in accordance to the EU rules. Such governance model also involves so many actors, legal basis and different competences.

The main issues on the CSRs and on the European economic governance had been brought up. The paper just highlighted main shortcoming of the European governance system and present some of the problems that are facing the EU's economic coordination.

The policy coordination is a very broad concept and the European economic governance/ES is a well-intentioned attempt to foster (macroeconomic) policy coordination between MSs. Because of the implications and complexity some of 
the recommendations classified as politically costly are less likely to be followed by policy implementation. Besides, it is difficult to determine which of the reforms being implemented by governments would have been taken forward in any case.

\section{REFERENCES}

1. Alcidi, C. and Gros, D. (2014) Implications of EU Governance Reforms Rationale and Practical Application ETLA Reports No. 25 http://pub.etla.fi/ETLA-

2. Alesina, A. and Perotti, R. (2004) TheEuropean Union: A Political Incorrect View, Journal of Economic Perspectives 18(4): 27-48.

3. Alesina, A., Spolaore, E. and Wacziarg, R. (1997) Economic Integration and Political Disintegration NBER Working Paper 6163, September 1997.

4. Bauer, M.W. and Becker, S. (2014)The Unexpected Winner of the Crisis: The European Commission's Strengthened Role in Economic Governance, Journal of European Integration, Vo. 36, No.3, 213-229.

5. Bickerton, C.J., Hodson, D. and Puetter, U.(2015) The New Intergovernmentalism: European Integration in the Post-Maastricht Era, Journal of Common Market Studies, Volume 53, Issue 4; July 2015.

6. Caporaso, J.A. (1998) Regional Integration Theory: Understanding Our Past and Anticipating Our Future in "European Integration and Supranational Governance" ed. by Sandholtz, W. and Stone Sweet, A.

7. Darvas, Z. and Leandro, A. (2015) The Limitations of Policy Coordination in the Euro Area under the European Semester, Bruegel Policy Contribution Papers, Issue 2015/19, November 2015.

8. Deroose, S. and Griesse, J. (2014) Implementing Economic Reforms - are EU Member States Responding to European Semester Recommendations?, ECFIN Economic Brief, Issue 37, October 2014.

9. De Streel, A. (2013) The Evolution of the EU Economic Governance Since the Treaty of Maastricht: An Unfinished Task, Maastricht Journal of European and Comparative Law 20 (3), 336-362.

10. Diez, T.and Wiener, A. (2018) Introducing the Mosaic of Integration Theory, KFG Working Paper Series No.88, May 2018.

11. Eberlein, B. and Kerwer, D. (2004) New Governance in the European Union: A Theoretical Perspective, JCMS 2004 Volume, Number 1., pp. $121-42$.

12. European Commission (2017) Communication from the Commission on 2017 European Semester: Country-specific recommendations

13. European Commission (2018) Communication from the Commission on 2018 European Semester: Country-specific recommendations

14. Efstathiou, K. and Wolff, G.B. (2018) Is the European Semester Effective and Useful?, Bruegel Policy Contribution Paper, Issue no. 09, June 2018. 
15. Gern,K-J., Jannsen, N. andKooths, S. (2015)Economic Policy Coordination in the Euro Area Under the European Semester, EP, ECON Paper November 2015

16. Goetz, K.H. and Meyer-Sahling, J-H. (2009) Political time in the EU: Dimensions, Perspectives, Theories,Journal of European Public Policy, 16:2 March 2009. pp. 180-201.

17. Hodson, D. and Maher, I. (2001) The Open Method as a New Mode of Governance: The Case of Soft Economic Policy Co-ordination, JCMS, Vol 39, No.4.

18. Hradisky, M. and Ciucci, M. (2018) Country-Specific Recommendations for 2017 and 2018" A Tabular Comparison and An Overview of Implementation, Study, EP September 2018.

19. Kohler-Koch, B. and Rittberger, B. (2006)Review Article: The 'Governance Turn' in EU Studies,JCMS, Vol 44, Annual Review pp.2749.

20. Lebessis, N. and Paterson, J. (1998) A Learning Organisation for Learning Society: Proposals for Designing Tomorrow's Commission, Forward Study Unit Working Paper.

21. Moravcsik, A. (1999) Is Something Rotten in the State of Denmark? Constructivism and European Integration, Journal of European Public Policy 6:4; Special Issues 1999; 669-81

22. Pisani-Ferry, J. (2018) Euro area reform: An Anatomy of the Debate, CEPR Policy Insight No. 95, October 2018.

23. Ragot, X. (2017) How to Further Strengthen the European Semester?EP, ECON Paper November 2017.

24. Rosamond, B. (2016) The Uniting of Europe and the Foundation of EU Studies: Revisiting the Neofunctionalism of Ernest B. Haas, Journal of European Public Policy” 12:2, April 2005; 237-254.

25. Schimmelfenning, F. (2018)European Integration Theory in Times of Crisis: A Comparison of the Euro and Schengen crisis, Journal of European Public Policy 25 (7), 969-989.

26. Schneider, J.D., Zuleeg, F. and Emmanouilidis, J.A. (2014) Policy Recommendations for the New European Commission: Priorities for Stabilising EMU, Discussion Paper, European Policy Centre, 30 September 2014.

27. Schuknecht, L. et al. (2011)The Stability and Growth Pact-Crisis and Reform, ECB Occasional Paper, No. 129

28. Spolaore, E. (2015) The Political Economy of European Integration, CESifo Working Paper No. 5247, February 2015.

29. Swyngedow, E. (2004) Globalisation: Networks, Territories and Rescaling, Cambridge Review of International Affairs, Volume 17, Number 1, pp. 2548, April 2004. 
30. Tommel, I. and Verdun, A. ed. (2009) Innovative Governance in the European Union: The Politics of Multilevel Policymaking, Lynne Rienner Publishers. (pp. 363)

31. Wallace, H. and Young, A. R. (1997) Participation and Policy-Making in the European Union, 280pp.

32. Wiener, A. (2018) Taking Stock of Integration Theory; KFG Working Paper No. 89; May 2018.

33. Zuleeg, F. (2015) Economic Policy Coordination in the Euro Area under the European Semester, EP, ECON Paper November 2017. 